\title{
Monitoring Trace Metal Contaminants in Green Mussel, Perna viridis from the Coastal Waters of Karnataka, Southwest Coast of India
}

\author{
Geetha Sasikumar, P. K. Krishnakumar, G. S. Bhat \\ Mangalore Research Centre of Central Marine Fisheries Research Institute, Post Box No. 244, Mangalore 575001 , Karnataka, India \\ Received: 28 February 2005/Accepted: 19 September 2005
}

\begin{abstract}
The green mussel (Perna viridis) is widely distributed in the coastal waters of Asia and is used in mussel watch programmes for monitoring environmental contaminants throughout the region. Green mussels representing different size groups and habitats were sampled from their natural beds at 28 locations in the inshore waters of Karnataka (southwest coast of India) to analyze the tissue concentrations of $\mathrm{Cd}, \mathrm{Cr}$, $\mathrm{Cu}, \mathrm{Fe}, \mathrm{Mn}, \mathrm{Ni}, \mathrm{Pb}$, and $\mathrm{Zn}$. Tissue concentrations of $\mathrm{Cr}, \mathrm{Cu}$, $\mathrm{Fe}$, and $\mathrm{Pb}$ were significantly higher in smaller mussels than in the larger size group. Significantly higher concentrations of $\mathrm{Cr}$, $\mathrm{Cu}, \mathrm{Fe}, \mathrm{Mn}$, and $\mathrm{Ni}$ were observed in mussels sampled from intertidal beds when compared to mussels from the subtidal beds. The sampling sites were categorized into industrial sites (IS), urban sites (US), and nonurban sites (NS) based on principal component analysis of metal concentrations in mussel. Spatial variations in tissue concentrations of all metals were observed except for $\mathrm{Zn}$. Generally, the levels of toxic trace metals like $\mathrm{Pb}, \mathrm{Cd}, \mathrm{Ni}$, and $\mathrm{Cr}$ in the whole tissue of $P$. viridis were within safe limits throughout the coast of Karnataka. However, relatively high concentrations of $\mathrm{Cd}, \mathrm{Cr}$, and $\mathrm{Pb}$ were observed in the whole tissue of green mussels collected from the industrial sites (IS), which may be derived from a variety of anthropogenic activities.
\end{abstract}

Trace metals in coastal waters are derived from a variety of natural and anthropogenic sources. Urban and industrial developments along the coastal areas, rivers, and estuaries contribute to the major part of the anthropogenic metal load of the sea (Ridwig et al. 2003; Cobelo-Garcia et al. 2004). Trace metals can be bioaccumulated in aquatic organisms. Due to the concerns over this accumulation and their toxic effects to humans consuming these organisms, monitoring programmes for metals in environmental (biotic and abiotic) samples have been widely established and implemented. The bioaccumulation of metals in benthic macroinvertebrates can provide an indication of the extent and magnitude of environmental contamination that is temporarily introduced via the water

Correspondence to: P. K. Krishnakumar; email: kkumarpk@ touchtelindia.net column and sediment. Thus, biomonitoring by employing living organisms such as mussels as sensors plays a vital role in governmental and industrial strategies to identify, assess, control, and reduce pollution problems (Krishnakumar et al. 1994, 1995).

The criteria by which organisms are accepted as biological indicators for the assessment of contamination were proposed more than 25 years ago and remain unchanged (Phillips 1976a, b; Fowler and Oregioni 1976). Marine bivalves, especially mussels, are widely used as sentinel organisms for coastal biomonitoring programmes due to their sessile nature, mode of feeding, ability to accumulate contaminants from the environment, and availability for human consumption. Distribution trace metals in the whole tissue and/or byssus threads of mussels has been extensively studied from both ecotoxicological and seafood safety points in several countries (Phillips 1976a, b; O'Conner 1992; Krishnakumar et al. 1994, 1995, 1997; Glynn et al. 2003; Nicholson and Szefer 2003; Szefer et al. 2004; Liu and Kueh 2005).

Green mussel (Perna viridis) is widely distributed in the coastal waters of Asia and is used in mussel watch programmes for monitoring environmental contaminants in the region (Lakshmanan and Nambisan 1983; Krishnakumar et al. 1990, 1998; Radhakrishnan 1993; Tewari et al. 2000, 2001; Monirith et al. 2003). Green mussels distributed throughout the west coast of India contribute a significant fishery of commercial importance. Along the Karnataka coast, natural mussel beds are located mostly in the subtidal zones attached to rocky substratum. Intertidal mussel beds are also found along the rocky coast in some areas. Besides the traditional fishery, the area also provides great potential for mussel mariculture as demonstrated by Central Marine Fisheries Research Institute (Mohamed et al. 1998). Being an important candidate species for mariculture (Nayar et al. 1980), they are farmed in many areas along the west coast of India as part of a rural development programme (Appukuttan et al. 2000).

Inshore waters of Karnataka (west coast of India) lying adjacent to Mangalore and Karwar receive treated effluent from several industrial sources including a caustic soda plant, fertilizer plant, iron ore processing plants, dyes and pigment processing plants, petroleum refinery, and other sources. About 12 towns located near the $300-\mathrm{km}$-long coastline discharge untreated sewage amounting to approximately $30 \mathrm{t} /$ day directly into the coastal waters (CPCB 1996). The Central 
Pollution Control Board of India has identified two cities, Karwar and Mangalore, on the Karnataka coast as pollution "hotspots" (CPCB 1996). Additionally, the coastal ecosystems on the southern part of the coast have been identified as "stressed" by anthropogenic activity (TERI 1999).

The distributions of heavy metals in the whole tissue of green mussel have been reported previously from the urban areas of Karnataka (Krishnakumar and Pillai 1990 Krishnakumar et al. 1990, 1998). However, detailed information on levels of toxic trace metals in natural populations of green mussels with varying size groups and categories of sites from the Karnataka coast is lacking. Hence the present study was planned to assess the levels of selected trace metals (Cd, $\mathrm{Cu}, \mathrm{Cr}, \mathrm{Fe}, \mathrm{Mn}, \mathrm{Ni}, \mathrm{Pb}$, and $\mathrm{Zn}$ ) in the whole tissue of green mussel $(P$. viridis) collected from various categories of sites covering 28 sampling stations, including islands, subtidal and intertidal beds covering a $300-\mathrm{km}$ coastline of Karnataka State, on the west coast of India.

\section{Materials and Methods}

\section{Characteristics of the Study Area}

The study area extending from Karwar in the north to Someshwara in the south (Fig. 1) consists of three coastal districts: Dakshina Kannada, Udupi, and Uttara Kannada. The coastal area, which is blessed with 14 perennial rivers, is increasingly subjected to urban development. Stations 2, 3, and 4 are located in the industrial belt where a fertilizer plant, iron ore processing plants, dye and pigment processing plants, petroleum refinery, among others, are located (Fig. 1). A major port is located between these stations at Panambur about $15 \mathrm{~km}$ north of Mangalore. Stations 8, 11, and 16 are located inside Fisheries harbours (Fig. 1)

\section{Mussel Sampling}

Mussel samples from their natural populations were collected from 28 locations during January 2002 (Fig. 1). Depending upon availability, mussels were collected from three different depths, $0 \mathrm{~m}$ (intertidal), $3.4 \mathrm{~m}(3-3.8 \mathrm{~m})$, and $5.4 \mathrm{~m}(5-5.8 \mathrm{~m})$, by engaging local divers and transported to the laboratory. The latitude and longitude of the sampling stations were marked using portable Global Positioning System (Garmin GPS, Model XL 12) with an accuracy of $\pm 5 \mathrm{~m}$. The shellfish were depurated overnight in clean and filtered seawater. The length of each individual mussel was measured and sorted according to their shell length before further analysis. The mussels were sorted as small (S) $<50 \mathrm{~mm}$, medium (M) $50-80 \mathrm{~mm}$, and large (L) $>80 \mathrm{~mm}$.

\section{Trace Metal Analysis}

Mussel samples were rinsed with distilled water, byssal threads removed, and wet shucked. Depending upon the availability, from each category (site, size, and depth), the whole tissue samples from 10 mussels were pooled, minced using sharp stainless steel scissors, and homogenized using a plastic spatula. Three such batches were used for the analysis. Approximately $1-2 \mathrm{~g}$ of tissue was digested with $10 \mathrm{ml}$ mixture of $\mathrm{HNO}_{3}$ and $\mathrm{H}_{2} \mathrm{O}_{2}$ ( $1: 1$ ratio) following standard procedure (Robisch and Clark 1993). The heavy metals in the digested samples were determined by Atomic Absorption Spectrophotometry with ei- ther air-acetylene flame (zinc) or graphite furnace (copper, cadmium, nickel, lead). The results were expressed in $\mu \mathrm{g} \mathrm{g}^{-1}$ wet tissue weight. Blanks and standards were digested with each sample set to provide quality control. The accuracy of the method was verified ( 10 replicates) using standard reference material (fish tissue, MA-B3/TM) obtained from the International Laboratory of Marine Radioactivity IAEA. Recoveries were above $90 \%$ for all the trace metals measured.

\section{Statistical Analysis}

One-way analysis of variance (ANOVA) was utilized to study the effect of size of mussels and depth of collection on the variations in concentrations of metals in mussel tissue (SPSS 12.00). After assessing the significance of the averages for each metal, range tests (Tukey's-b and $\mathrm{S}-\mathrm{N}-\mathrm{K}$ ) were carried out to obtain homogeneous subsets of means. The data set from homogeneous size groups were pooled and subjected to principal component analysis for grouping of sampling sites.

\section{Results}

\section{Size-Dependent Trend}

The mean concentrations of $\mathrm{Cd}, \mathrm{Cr}, \mathrm{Cu}, \mathrm{Fe}, \mathrm{Mn}, \mathrm{Ni}$, and $\mathrm{Pb}$ in the whole tissue $\left(\mu \mathrm{g} \mathrm{g}^{-1}\right.$ wet wt) of $P$. viridis in different size groups along Karnataka coast are shown in Table 1 . The tissue concentration of $\mathrm{Cd}$ in smaller mussels varied from 0.24 to $3.49, \mathrm{Cr}$ from below detectable level (nd) to $0.40, \mathrm{Cu}$ from nd to 1.67 , Fe from 35.52 to $235.60, \mathrm{Mn}$ from 1.91 to $8.77, \mathrm{Ni}$ from nd to $1.87, \mathrm{~Pb}$ from nd to 1.95 , and $\mathrm{Zn}$ from nd to $16.91 \mu \mathrm{g} \mathrm{g}^{-1}$ wet wt. The tissue concentration of $\mathrm{Cd}$ from medium-sized mussels varied from 0.28 to $1.95, \mathrm{Cr}$ from nd to $0.46, \mathrm{Cu}$ from nd to $1.75, \mathrm{Fe}$ from nd to $145.46, \mathrm{Mn}$ from 2.62 to 8.57 , Ni from nd to $1.47, \mathrm{~Pb}$ from nd to 1.96 , and $\mathrm{Zn}$ from nd to $17.36 \mu \mathrm{g} \mathrm{g}^{-1}$ wet wt. Among the larger mussels, the tissue concentration of $\mathrm{Cd}$ varied from 0.52 to $1.55, \mathrm{Cr}$ from nd to $0.12, \mathrm{Cu}$ from nd to $1.843, \mathrm{Fe}$ from 14.56 to $68.21, \mathrm{Mn}$ from 2.59 to 6.88 , Ni from nd to $2.89, \mathrm{~Pb}$ from nd to 0.64 , and $\mathrm{Zn}$ from 6.76 to $13.23 \mu \mathrm{g} \mathrm{g}^{-1}$ wet wt.

Variations in the trace metal concentrations in tissues of different sized mussels from the sampling sites are presented in Table 2. Sizewise distributions of $\mathrm{Cr}, \mathrm{Cu}, \mathrm{Fe}$, and $\mathrm{Pb}$ in the whole tissue of mussels were statistically significant $(p<0.05)$ by ANOVA. Tissue concentrations of $\mathrm{Cr}, \mathrm{Cu}, \mathrm{Fe}$, and $\mathrm{Pb}$ were significantly lower (Table 2) in larger mussels than in the smaller size groups $(p<0.05$, S-N-K and Tukey s-b). No significant differences among size groups in $\mathrm{Cd}, \mathrm{Mn}, \mathrm{Ni}$, and $\mathrm{Zn}$ concentrations were observed.

\section{Tidal Effect}

In the present study, the $\mathrm{Cr}, \mathrm{Cu}, \mathrm{Fe}, \mathrm{Mn}$, and Ni showed significantly higher levels in mussels collected from intertidal beds (Fig. 2) than in mussels collected from subtidal beds. There was no significant difference between the concentrations of $\mathrm{Cd}, \mathrm{Pb}$, and $\mathrm{Zn}$ in mussels from intertidal and subtidal beds. However, the mean concentrations of $\mathrm{Pb}$ and $\mathrm{Zn}$ were higher in intertidal mussels and that of $\mathrm{Cd}$ was higher in subtidal mussels. 


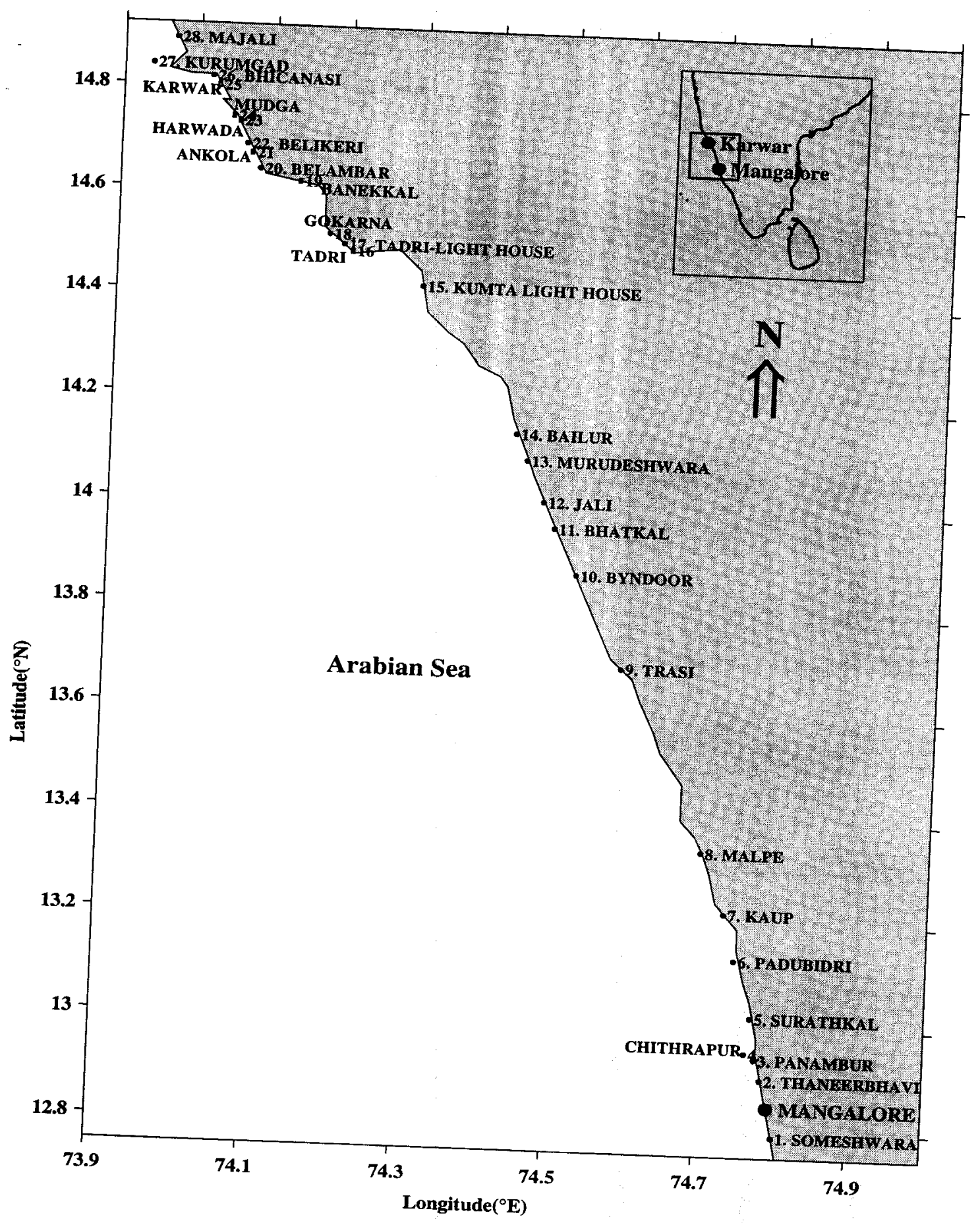

Fig. 1. Map showing the mussel sampling sites in the coastal waters of Karnataka (west coast of India)

\section{Spatial Trends}

The mean concentrations of $\mathrm{Cd}, \mathrm{Cr}, \mathrm{Cu}, \mathrm{Fe}, \mathrm{Mn}, \mathrm{Ni}$, and $\mathrm{Pb}$ in the whole tissue $\left(\mu \mathrm{g} \mathrm{g}^{-1}\right.$ wet $\left.\mathrm{wt}\right)$ of smaller and medium-sized (homogeneous size groups as shown in Table 2) mussels from Fig. 3, the results only used for grouping of sampling sites. In Fig. 3, the results of the principal component analysis (PCA) are presented in a scatterplot. The first two principal components (PC1 and PC2) are responsible for some $49.7 \%$ of the data scatter. Ordination on PC1 (variance 28.9\%) mostly corresponds to samples collected from the industrial sites, stations 2, 3, 4, in addition to a Fisheries harbour (Station 11) and urban sites nos. $24,25,26,27$. There was strong separation of the northern sites from the southern sites. PC2 (variance 
Table 1. Concentration of trace metals in the whole tissue ( $\mu \mathrm{g} / \mathrm{g}$ wet wt) of green mussel, Perna viridis, belonging to different size groups [Small (S) $<50 \mathrm{~mm}$, Medium (M) $50-80 \mathrm{~mm}$, Large (L) $>80 \mathrm{~mm}$ ] collected from the coastal waters of Karnataka, west coast of India (mean \pm SD)

\begin{tabular}{|c|c|c|c|c|c|c|c|c|c|}
\hline Site code & Size & $\mathrm{Cd}$ & $\mathrm{Cr}$ & $\mathrm{Cu}$ & $\mathrm{Fe}$ & Mn & $\mathrm{Ni}$ & $\mathrm{Pb}$ & $Z_{n}$ \\
\hline \multirow[t]{3}{*}{1} & $\mathbf{S}$ & $1.10 \pm 0.29$ & nd & nd & $35.51 \pm 63.28$ & $5.13 \pm 2.08$ & nd & nd & $9.74 \pm 0.93$ \\
\hline & $\mathbf{M}$ & $0.75 \pm 0.40$ & nd & nd & $11.75 \pm 23.51$ & $5.23 \pm 2.71$ & nd & nd & $12.74 \pm 2.61$ \\
\hline & $\mathrm{L}$ & $0.51 \pm 0.23$ & nd & $0.39 \pm 0.46$ & $21.53 \pm 16.41$ & $3.29 \pm 0.23$ & $0.48 \pm 0.96$ & nd & $11.44 \pm 1.49$ \\
\hline 2 & $\mathbf{S}$ & $0.53 \pm 0.16$ & $0.23 \pm 0.01$ & $0.08 \pm 0.12$ & $90.00 \pm 62.37$ & $3.56 \pm 1.04$ & $1.23 \pm 0.16$ & $1.94 \pm 0.04$ & $9.71 \pm 0.48$ \\
\hline 3 & $\mathbf{M}$ & $1.44 \pm 0.03$ & $0.46 \pm 0.18$ & $0.56 \pm 0.11$ & $91.65 \pm 36.42$ & $2.61 \pm 0.54$ & $0.23 \pm 0.16$ & $1.95 \pm 0.02$ & $10.77 \pm 1.51$ \\
\hline 4 & $\mathbf{S}$ & $3.48 \pm 0.27$ & $0.28 \pm 0.08$ & $1.02 \pm 0.16$ & $86.37 \pm 25.32$ & $3.25 \pm 0.74$ & $0.53 \pm 0.23$ & $1.90 \pm 0.08$ & $9.48 \pm 0.50$ \\
\hline \multirow[t]{2}{*}{5} & $\mathrm{~S}$ & $0.55 \pm 0.17$ & nd & $0.19 \pm 0.30$ & $94.49 \pm 134.54$ & $1.91 \pm 2.34$ & nd & nd & $8.57 \pm 0.81$ \\
\hline & $\mathbf{M}$ & $1.51 \pm 0.24$ & $0.05 \pm 0.09$ & $0.06 \pm 0.18$ & $31.49 \pm 84.27$ & $3.06 \pm 1.64$ & nd & nd & $9.36 \pm 4.34$ \\
\hline 6 & $\mathbf{M}$ & $1.60 \pm 0.19$ & nd & nd & $60.25 \pm 79.06$ & $3.77 \pm 0.17$ & nd & nd & $7.45 \pm 1.92$ \\
\hline 7 & $\mathrm{~S}$ & $0.68 \pm 0.12$ & nd & $0.54 \pm 0.27$ & $85.34 \pm 39.95$ & $3.54 \pm 0.22$ & $0.71 \pm 0.13$ & nd & $10.57 \pm 2.08$ \\
\hline 8 & $\mathbf{M}$ & $1.32 \pm 0.36$ & nd & nd & nd & $3.41 \pm 0.05$ & nd & nd & $5.96 \pm 0.92$ \\
\hline \multirow[t]{2}{*}{9} & $\mathbf{M}$ & $1.80 \pm 0.07$ & nd & $0.89 \pm 0.07$ & $38.04 \pm 0.11$ & $2.63 \pm 0.30$ & nd & $0.39 \pm 0.23$ & $12.31 \pm 0.19$ \\
\hline & $\mathrm{L}$ & $1.36 \pm 0.19$ & nd & nd & $14.55 \pm 17.10$ & $2.59 \pm 1.11$ & nd & nd & $6.75 \pm 2.3$ \\
\hline \multirow[t]{2}{*}{10} & $\mathbf{M}$ & $1.23 \pm 0.03$ & nd & nd & $122.32 \pm 34.61$ & $8.27 \pm 0.57$ & nd & nd & $8.52 \pm 1.65$ \\
\hline & $\mathrm{L}$ & $1.20 \pm 0.53$ & $0.012 \pm 0.03$ & $0.05 \pm 0.13$ & $45.80 \pm 46.75$ & $6.29 \pm 1.6$ & $0.04 \pm 0.10$ & nd & $9.47 \pm 1.62$ \\
\hline 11 & $S$ & $1.16 \pm 1.61$ & $0.39 \pm 0.13$ & $0.45 \pm 0.55$ & $48.36 \pm 19.04$ & $6.41 \pm 0.52$ & nd & $1.81 \pm 0.01$ & $8.02 \pm 0.58$ \\
\hline 12 & $\mathrm{~L}$ & $1.55 \pm 0.07$ & nd & nd & $61.82 \pm 19.17$ & $6.34 \pm 0.85$ & nd & $0.52 \pm 0.06$ & $8.70 \pm 2.63$ \\
\hline 13 & $\mathrm{~L}$ & $1.44 \pm 0.06$ & nd & nd & $53.40 \pm 46.86$ & $4.37 \pm 0.25$ & nd & nd & $8.57 \pm 1.79$ \\
\hline 14 & $\mathrm{~L}$ & $1.14 \pm 0.08$ & nd & nd & $68.21 \pm 30.97$ & $4.89 \pm 0.74$ & nd & $0.64 \pm 0.08$ & $9.12 \pm 2.17$ \\
\hline 15 & $\mathbf{M}$ & $1.95 \pm 0.35$ & nd & nd & $93.53 \pm 17.22$ & $7.32 \pm 0.31$ & nd & $1.45 \pm 0.64$ & nd \\
\hline 16 & $\mathbf{M}$ & $1.60 \pm 0.28$ & nd & $0.21 \pm 0.30$ & $61.65 \pm 77.91$ & $5.66 \pm 0.59$ & nd & $1.53 \pm 0.51$ & $14.48 \pm 20.48$ \\
\hline 17 & $\mathbf{M}$ & $1.95 \pm 0.49$ & $0.06 \pm 0.08$ & $1.15 \pm 1.63$ & $125.45 \pm 26.42$ & $7.41 \pm 2.63$ & nd & $0.10 \pm 0.01$ & $17.02 \pm 24.08$ \\
\hline 18 & $\mathbf{S}$ & $0.37 \pm 0.10$ & nd & $1.18 \pm 0.31$ & $86.57 \pm 33.87$ & $6.19 \pm 1.69$ & nd & nd & $11.51 \pm 6.75$ \\
\hline 19 & $\mathbf{M}$ & $1.25 \pm 0.07$ & nd & $0.88 \pm 0.10$ & $106.28 \pm 5.22$ & $3.75 \pm 0.10$ & nd & $0.61 \pm 0.06$ & $12.52 \pm 17.71$ \\
\hline 20 & $\mathbf{M}$ & $1.16 \pm 0.52$ & nd & $1.00 \pm 0.01$ & $118.93 \pm 16.35$ & $4.26 \pm 0.17$ & nd & $0.67 \pm 0.28$ & $11.87 \pm 16.8$ \\
\hline 21 & $\mathbf{S}$ & $0.24 \pm 0.05$ & $0.14 \pm 0.13$ & $1.33 \pm 0.06$ & $186.52 \pm 57.2$ & $5.69 \pm 0.86$ & nd & nd & $16.91 \pm 4.98$ \\
\hline 22 & $\mathbf{M}$ & $0.32 \pm 0.01$ & nd & $0.89 \pm 0.17$ & $117.06 \pm 29.55$ & $5.22 \pm 0.44$ & nd & nd & $17.35 \pm 9.37$ \\
\hline 23 & $S$ & $1.05 \pm 0.07$ & nd & $0.75 \pm 1.07$ & $235.60 \pm 22.49$ & $7.02 \pm 0.01$ & nd & $0.86 \pm 1.22$ & nd \\
\hline 24 & $\mathbf{M}$ & $0.27 \pm 0.12$ & $0.27 \pm 0.20$ & $1.55 \pm 0.37$ & $145.45 \pm 66.21$ & $7.14 \pm 1.75$ & $0.58 \pm 0.44$ & nd & $9.12 \pm 1.81$ \\
\hline \multirow[t]{2}{*}{25} & $\mathbf{M}$ & $1.19 \pm 0.03$ & $0.10 \pm 0.10$ & $1.75 \pm 0.34$ & $39.55 \pm 13.75$ & $8.57 \pm 1.89$ & $1.46 \pm 1.51$ & nd & $10.92 \pm 1.58$ \\
\hline & $\mathrm{L}$ & $1.54 \pm 0.08$ & $0.12 \pm 0.06$ & $1.84 \pm 0.47$ & $39.08 \pm 7.63$ & $6.88 \pm 0.51$ & $2.88 \pm 0.87$ & nd & $13.22 \pm 2.11$ \\
\hline 26 & $\mathbf{S}$ & $0.48 \pm 0.61$ & $0.18 \pm 0.07$ & $1.66 \pm 0.08$ & $48.39 \pm 2.26$ & $7.64 \pm 0.18$ & $1.40 \pm 0.15$ & nd & $14.07 \pm 1.06$ \\
\hline 27 & $S$ & $0.28 \pm 0.05$ & $0.14 \pm 0.06$ & $1.38 \pm 0.19$ & $40.69 \pm 1.69$ & $8.49 \pm 0.43$ & $1.87 \pm 0.01$ & nd & $7.47 \pm 0.90$ \\
\hline 28 & $\mathbf{S}$ & $1.70 \pm 0.14$ & nd & $0.35 \pm 0.49$ & $92.43 \pm 40.7$ & $8.77 \pm 1.12$ & nd & $1.23 \pm 0.15$ & $10.05 \pm 0.08$ \\
\hline
\end{tabular}

nd, not detectable.

Table 2. Trace metal concentrations ( $\mu \mathrm{g} / \mathrm{g}$ wet $\mathrm{wt})$ in the whole tissue (mean $\pm \mathrm{SD}$ ) of different sized mussels (Perna viridis)

\begin{tabular}{llllrrrrr}
\hline Size group & Cd & \multicolumn{1}{l}{$\mathrm{Cr}^{*}$} & $\mathrm{Cu}$ & $\mathrm{Fe}$ & $\mathrm{Mn}$ & $\mathrm{Ni}$ & $\mathrm{Pb}$ & $\mathrm{Zn}^{*}$ \\
\hline Small & $1.08 \pm 0.98$ & $0.09^{\mathrm{a}} \pm 0.13$ & $0.60^{\mathrm{a}} \pm 0.62$ & $81.04^{\mathrm{a}} \pm 74.7$ & $5.24 \pm 2.39$ & $0.33 \pm 0.57$ & $0.5 \pm 0.82$ & $9.72 \pm 3.84$ \\
Medium & $1.26 \pm 0.52$ & $0.07^{\mathrm{ab}} \pm 0.14$ & $0.60^{\mathrm{a}} \pm 0.73$ & $64.89^{\mathrm{ab}} \pm 66.4$ & $5.13 \pm 2.55$ & $0.24 \pm 0.71$ & $0.25^{\mathrm{ab}} \pm 0.53$ & $10.46 \pm 7.3$ \\
Large & $1.19 \pm 0.46$ & $0.01^{\mathrm{b}} \pm 0.04$ & $0.23^{\mathrm{b}} \pm 0.53$ & $40.29^{\mathrm{b}} \pm 35.9$ & $5.05 \pm 1.91$ & $0.31 \pm 0.87$ & $0.09^{\mathrm{b}} \pm 0.22$ & $9.49 \pm 2.38$ \\
\hline
\end{tabular}

* Significantly different groups marked $(p<0.05)$ with letters $a, b$, and $c$.

$20.8 \%$ ) allowed us to differentiate between the industrial and urban sites from the nonurban sites. The sampling sites were categorized into industrial sites (IS) urban sites (US), and nonurban sites (NS) depending upon the PCA.

Table 3 lists the mean concentration of $\mathrm{Cd}, \mathrm{Cr}, \mathrm{Cu}, \mathrm{Fe}, \mathrm{Mn}$, $\mathrm{Ni}$, and $\mathrm{Pb}$ in the whole tissue $\left(\mu \mathrm{g} \mathrm{g}^{-1}\right.$ wet wt) of $P$. viridis from the different categories of sampling sites along Karnataka coast. Among the three different categories of sites, the mean concentration of $\mathrm{Cd}$ ranged from 0.70 to $2.02, \mathrm{Cr}$ from 0.012 to $0.33, \mathrm{Cu}$ from 0.36 to $1.63, \mathrm{Fe}$ from 70.83 to $80.55, \mathrm{Mn}$ from 3.81 to 8.01 , Ni from 0.02 to 1.26 , Pb from below detectable level (ND) to 1.9 , and $\mathrm{Zn}$ from 9.49 to $10.36 \mu \mathrm{g} \mathrm{g}^{-1}$ wet wt. Maximum concentrations of $\mathrm{Cd}, \mathrm{Cr}, \mathrm{Fe}$, and $\mathrm{Pb}$ were recorded in the industrial areas (IS).
The variability of trace metals in different categories of sites by analysis of variance (ANOVA) is presented in Table 3 . Among the three categories of sites, distribution of $\mathrm{Cd}, \mathrm{Cr}$, and $\mathrm{Pb}$ was significantly (Table 3$)$ higher $(p<0.05$, NewmanKeuls) in mussels collected from IS.

\section{Correlations of Metals}

Correlation between concentrations of metals in whole tissue of $P$. viridis is given in Table $4 . \mathrm{Pb}$ correlated significantly with $\mathrm{Cd}$ and $\mathrm{Cr}(p<0.01)$ while $\mathrm{Cu}$ showed strong correlation with $\mathrm{Cr}, \mathrm{Fe}, \mathrm{Mn}, \mathrm{Ni}$, and $\mathrm{Zn}(p<0.01$ and $p<0.05)$. 

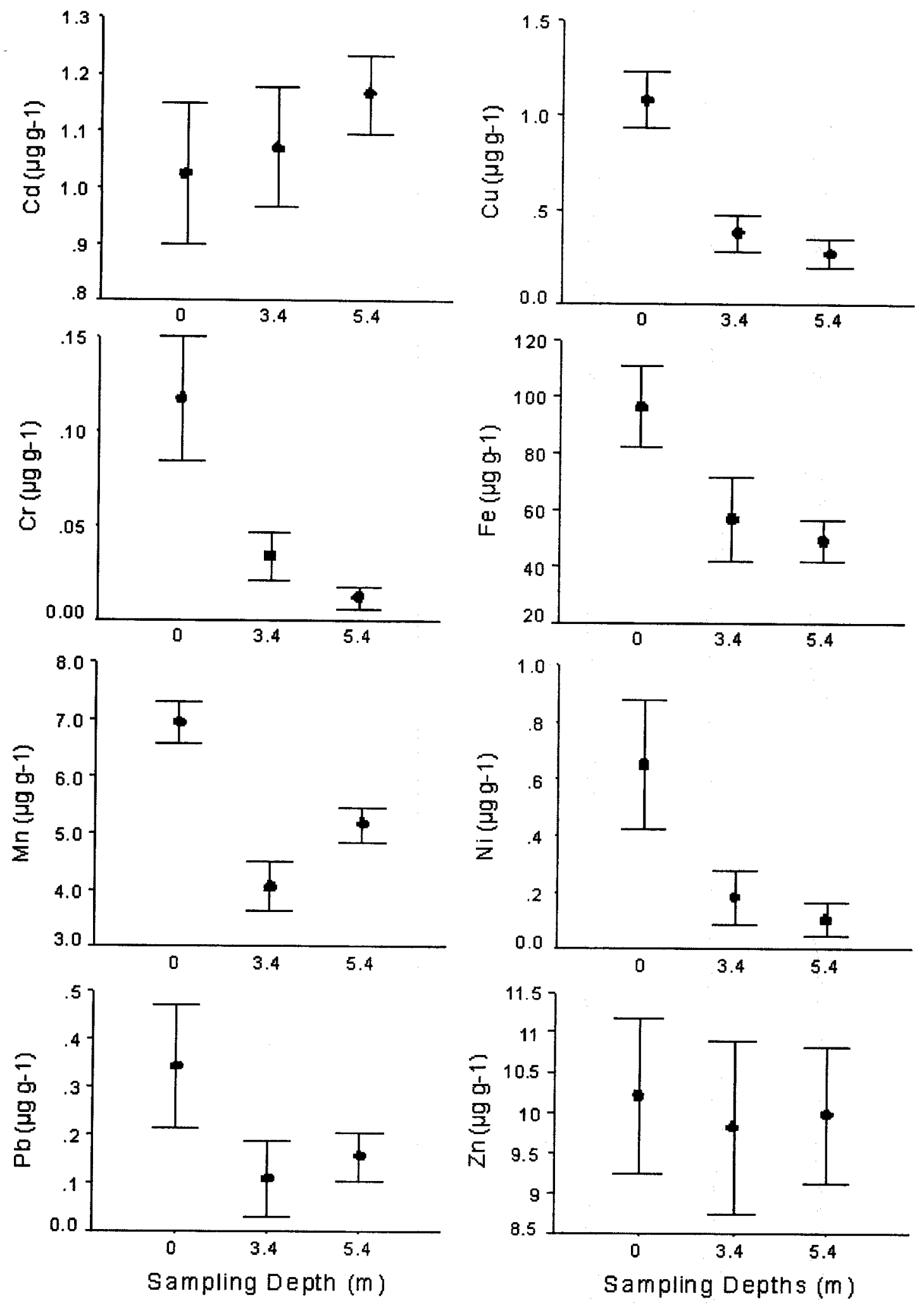

Fig. 2. Trace metal (mean $+\mathrm{SD}$ ) concentrations ( $\mu \mathrm{g} / \mathrm{g}$ wet wt) in the whole tissue of natural populations of green mussel (Perna viridis) collected from three depths (intertidal: $0 \mathrm{~m}$; subtidal: $3.4 \mathrm{~m}$ and $5.4 \mathrm{~m}$ ) from the coastal waters of Karnataka 


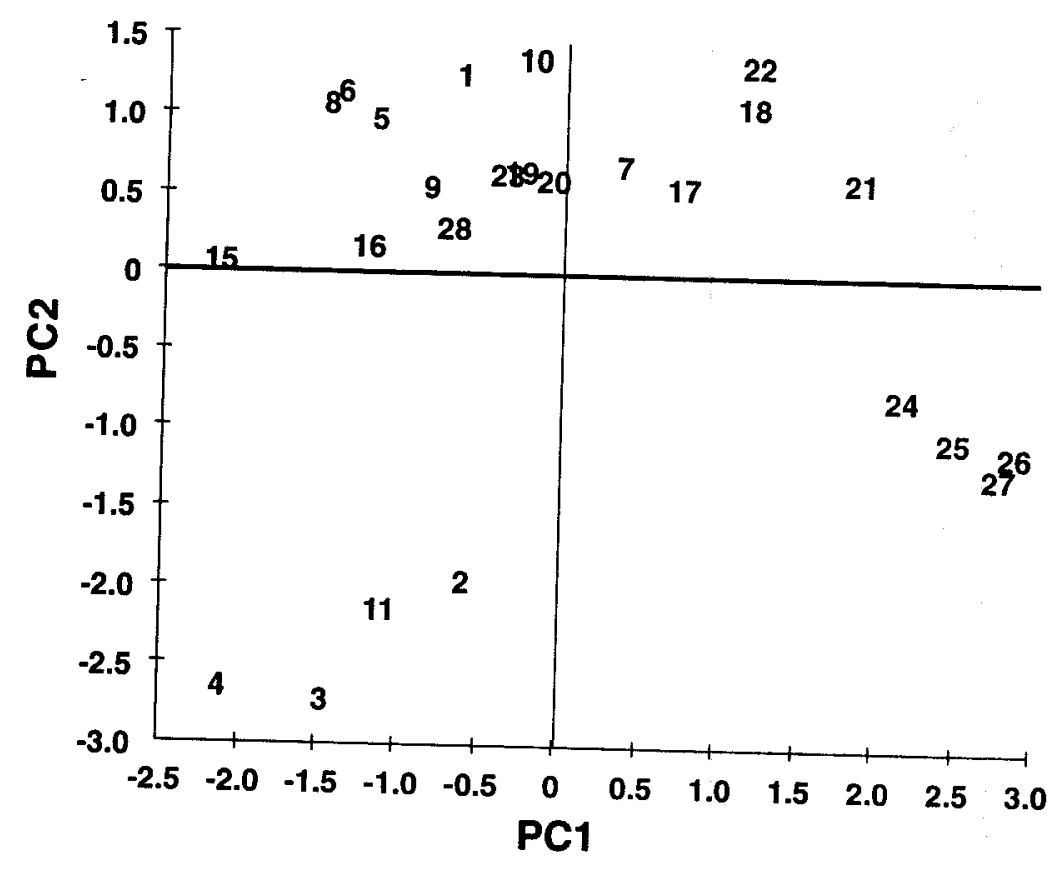

Fig. 3. Scatterplot of the sampling site scores (PCA) in space spanned by axis $\mathrm{PC} 1$ and $\mathrm{PC} 2$ of metal concentrations in green mussel $(<80 \mathrm{~mm})$ For site codes refer to Figure 1 Table 3. Mean concentrations of trace metals in the whole tissue $\left(\mu \mathrm{g} \mathrm{g}^{-1}\right.$ wet $\mathrm{wt}$ ) of green mussel, Perna viridis, collected from industrial sites
(IS), urban sites (US), and nonurban sites (NS) with intersite variability (ANOVA)

\begin{tabular}{llllllllr} 
Site category & $\mathrm{Cd}$ & $\mathrm{Cr}$ & $\mathrm{Cu}$ & $\mathrm{Fe}$ & $\mathrm{Mn}$ & $\mathrm{Ni}$ & $\mathrm{Pb}$ & $\mathrm{Zn}$ \\
\hline IS & $2.02^{\mathrm{a}} \pm 1.41$ & $0.33^{\mathrm{a}} \pm 0.12$ & $0.62^{\mathrm{a}} \pm 0.43$ & $80.55 \pm 33.56$ & $3.81^{\mathrm{a}} \pm 1.53$ & $0.50^{\mathrm{a}} \pm 0.46$ & $1.90^{\mathrm{a}} \pm 0.07$ & $9.49 \pm 1.12$ \\
US & $0.70^{\mathrm{b}} \pm 0.48$ & $0.17^{\mathrm{b}} \pm 0.16$ & $1.63^{\mathrm{b}} \pm 0.31$ & $71.24 \pm 58.88$ & $8.01^{\mathrm{b}} \pm 1.59$ & $1.26^{\mathrm{b}} \pm 1.07$ & $0.00^{\mathrm{b}}$ & $10.36 \pm 2.43$ \\
NS & $1.16^{\mathrm{b}} \pm 0.53$ & $0.012^{\mathrm{c}} \pm 0.05$ & $0.36^{\mathrm{a}} \pm 0.54$ & $70.83 \pm 77.16$ & $4.76^{\mathrm{a}} \pm 2.30$ & $0.02^{\mathrm{c}} \pm 0.13$ & $0.22^{\mathrm{b}} \pm 0.49$ & $10.18 \pm 6.98$ \\
All sites & $1.18 \pm 0.76$ & $0.08 \pm 0.14$ & $0.60 \pm 0.68$ & $72.02 \pm 70.23$ & $5.18 \pm 2.47$ & $0.28 \pm 0.65$ & $0.38 \pm 0.70$ & $10.13 \pm 6.00$ \\
F & $11.22^{*}$ & $64.43^{*}$ & $36.71^{*}$ & 0.08 & $15.75^{*}$ & $42.16^{*}$ & $75.39^{*}$ & 0.07 \\
\hline * Significantly different groups & & &
\end{tabular}

* Significantly different groups marked $(p<0.05)$ with letters a, b, and c.

Table 4. Correlation between tissue concentrations of metals in Perna viridis from coastal waters of Karnataka $(p<0.05)$

\begin{tabular}{lllll}
\hline $\mathrm{Cd}$ & $(+) \mathrm{Pb}$ & & & \\
\hline $\mathrm{Cr}$ & $(+) \mathrm{Cu}$ & $(+) \mathrm{Fe}$ & $(+) \mathrm{Ni}$ & $(+) \mathrm{Pb}$ \\
$\mathrm{Cu}$ & $(+) \mathrm{Cr}$ & $(+) \mathrm{Fe}$ & $(+) \mathrm{Mn}$ & $(+) \mathrm{Ni}$ \\
$\mathrm{Fe}$ & $(+) \mathrm{Cr}$ & $(+) \mathrm{Cu}$ & $(+) \mathrm{Mn}$ & \\
$\mathrm{Mn}$ & $(+) \mathrm{Cu}$ & $(+) \mathrm{Fe}$ & $(+) \mathrm{Ni}$ & \\
$\mathrm{Ni}$ & $(+) \mathrm{Cr}$ & $(+) \mathrm{Cu}$ & $(+) \mathrm{Mn}$ & \\
$\mathrm{Pb}$ & $(+) \mathrm{Cd}$ & $(+) \mathrm{Cr}$ & & \\
$\mathrm{Zn}$ & $(+) \mathrm{Cu}$ & & & \\
\hline
\end{tabular}

$(+)=$ positive correlation $(-)=$ negative correlation

Significant positive correlations $(p<0.01$ and $p<0.05)$ were also observed between $\mathrm{Zn}$ and $\mathrm{Cu}$.

\section{Discussion}

The mean tissue concentrations of toxic trace metals in $P$. viridis collected from 28 sampling sites along the Karnataka coast were found to be below the WHO permissible concentrations given for seafood (WHO 1972, 1987). The Cd levels in green mussels from industrial areas slightly exceeded the WHO permissible level for seafood (Table 3 ).

The variations in $\mathrm{Cr}, \mathrm{Cu}, \mathrm{Fe}$, and $\mathrm{Pb}$ accumulation by mussels of different size groups were found statistically significant (Table 2). Statistically significant negative correlations were observed between mussel size and tissue concentrations of $\mathrm{Cr}, \mathrm{Cu}, \mathrm{Fe}$, and $\mathrm{Pb}$. Szefer et al. (2004) observed a similar negative correlation between trace metals such as $\mathrm{Cr}, \mathrm{Fe}, \mathrm{Mn}, \mathrm{Ni}, \mathrm{Sn}$, and $\mathrm{Ti}$ levels and size in blue mussels. In the present study, $\mathrm{Cu}, \mathrm{Cr}, \mathrm{Fe}$, and $\mathrm{Pb}$ concentrations were significantly higher in smaller mussels compared to 
larger mussels. Airas (2003) reported a similar negative trend for $\mathrm{Cu}$ in $M$. edulis. Such a relationship was also observed in $M$. edulis by Brix and Lyngby (1985) for Cr. According to Brix and Lyngby (1985) and Otchere (2003), the uptake of metals in bivalves was higher in smaller individuals than in larger ones generally resulting in a "growth dilution effect." In this way, while the metal burden would increase with age, concentration would diminish with the weight/size within each age class, if growth were more rapid than the accumulation rate. In the present study, no significant differences in $\mathrm{Cd}, \mathrm{Mn}, \mathrm{Ni}$, and $\mathrm{Zn}$ concentrations were observed among different size groups. Riget et al. (1996) observed $\mathrm{Zn}$ to be independent of size.

In the present study, the $\mathrm{Cr}, \mathrm{Cu}, \mathrm{Fe}, \mathrm{Mn}$, and $\mathrm{Ni}$ showed significantly higher concentrations in intertidal mussels when compared to subtidal mussels between $3 \mathrm{~m}$ and $5 \mathrm{~m}$ deep (Fig. 2). No significant differences were found in concentrations of $\mathrm{Cd}, \mathrm{Pb}$, and $\mathrm{Zn}$ in mussels from intertidal beds compared to subtidal beds. However, the mean concentrations of $\mathrm{Pb}$ and $\mathrm{Zn}$ were high in intertidal mussels while concentrations of $\mathrm{Cd}$ were higher in subtidal mussels (Fig. 2). Phillips (1976a, b) recorded the highest values of $\mathrm{Zn}, \mathrm{Cd}$, and $\mathrm{Pb}$ levels in intertidal mussels collected at low saline waters. According to Schulz-Baldes (1974), blue mussels take up cadmium in dissolved form, while lead is taken up from food particles and from water in similar rates. A common feature of metal distributions is a general tendency for decreasing concentrations in the offshore directions. This feature is caused by a high concentration of heavy metals in land-based suspended matter supplied to the bay from surface run-off. Similar metal distribution was observed by Borg and Jonsson (1996) and Pempkowiak et al. (2005) in coastal areas.

The analysis of variance in tissue concentrations of $\mathrm{Cd}, \mathrm{Cr}$, $\mathrm{Cu}, \mathrm{Mn}, \mathrm{Ni}$, and $\mathrm{Pb}$ was significantly different $(p<0.01)$ between the different categories of sites. Lead concentrations observed in $P$. viridis in the present study were $2-4$ times lower than those reported by Krishnakumar et al. (1998) along the Karnataka coast. (It was below the detectable levels in tissues from the majority of sites from NS.) The observed decrease in bioaccumulation of lead in mussels may be due to the recent practice of using unleaded motor fuel.

To obtain homogeneous groups for metal accumulation in mussels, a range test (Newman-Keuls test) was performed, which revealed the presence of two homogeneous groups of sites, namely IS and other sites. Increased concentrations of $\mathrm{Pb}$ in mussels from IS were observed when compared to US and NS (Table 3). The samples from IS were taken from buoys kept afloat near the navigational channel of the major port, which receives input from industries including a refinery and dye and pigment manufacturing plant. In the IS, the industrial input of lead as well as that from fuel can produce such a marked effect. The importance of fuels as a source of lead in the marine environment is discussed by Phillips $(1976 \mathrm{a}, \mathrm{b})$, which can cause a high concentration of tetra-ethyl lead in the vicinity of marinas. Fowler (2002) found higher levels of $\mathrm{Pb}$ in bivalves from areas subjected to substantial nonoil and oil industrial inputs in the Middle East. Szefer et al. (2004) attributed elevated levels of $\mathrm{Pb}$ and $\mathrm{Cd}$ accumulation in Mytilus galloprovincialis from Onsan Harbour, Korea, to shipping and industrial activities.

In the present study, $\mathrm{Cd}$ and $\mathrm{Cr}$ concentrations in mussels from IS were significantly higher when compared to other categories of sites (Table 3). A range test revealed two homogeneous subgroups for $\mathrm{Cd}$ bioaccumulation, the first comprising IS and the second comprising the other two categories (Table 3). When compared with earlier studies (Krishnakumar et al. 1998) from IS, the Cd concentrations recorded in the present study were three times higher. Mohankumar et al. (2003) observed as high as $14.90 \mu \mathrm{g} / \mathrm{g}$ of Cd and $177 \mu \mathrm{g} / \mathrm{g}$ of $\mathrm{Cr}$ in macrobenthos, consisting mainly of molluscs, from the industrial area off the Mangalore coast. In the present study, $\mathrm{Cr}$ was the least accumulated of the eight metals studied. Low levels of $\mathrm{Cd}$ were recorded in mussels collected from islands off Uttara Kannada district. Similar trends were reported by Krishnakumar et al. (1990) in $P$. viridis collected from Sungeri Island near Karwar.

High Fe levels were evident in all the sites and Fe accumulation was highest among the metals studied. Relatively consistent tissue concentrations of $\mathrm{Zn}$ were observed in mussels throughout the coast. There was no significant difference in the distribution of $\mathrm{Zn}$ in mussel tissues between the different categories of sites. Like $\mathrm{Fe}, \mathrm{Zn}$ concentrations in the mussel were high and comparable with similar studies (Table 5) reported by Sankaranarayanan et al. (1976) and Krishnakumar et al. (1998) and relatively lower than those reported by other authors from Indian waters (Zingde et al. 1976; Rajendran et al. 1988; Senthilnathan et al. 1998; Radhakrishnan 1993; Tewari et al. 2000, 2001). The highest values for $\mathrm{Zn}$ were found in NS followed by IS. Krishnakumar et al. (1998) recorded $\mathrm{Zn}$ values as high as $72 \mu \mathrm{g} \mathrm{g}^{-1}$ dry wt in the sediments from the coastal waters of Karnataka. Concentrations of the toxic trace metals in green mussels were clearly below the limit set by WHO for seafood (WHO, 1972, 1987).

$\mathrm{Cu}$ levels detected in the present study were comparable (Table 5) with earlier studies from nonurban sites of Karnataka; on the other hand, the $\mathrm{Cu}$ levels were lower when compared to industrial and urban sites of Karnataka (Krishnakumar et al. 1998) and those reported by other authors in Indian waters (Zingde et al. 1976; Rajendran et al. 1988 Senthilnathan et al. 1998; Radhakrishnan 1993; Tewari et al. 2000,2001 ). Ni concentrations were below detectable levels in green mussels from a majority of the sampling stations along the coast. The data available on $\mathrm{Ni}$ and $\mathrm{Cr}$ concentrations in mussel tissue from this coast is scarce. However, the concentration of $\mathrm{Ni}$ recorded in the present study remained within the ranges previously reported from green mussel from Cochin and Calicut waters (Radhakrishnan 1993), though some authors have reported higher levels in green mussels from the coastal waters of Gujarat (Tewari et al. 2000, 2001).

A significant positive correlation of $\mathrm{Cu}(p<0.01$ and $p<0.05$ ) with $\mathrm{Cr}, \mathrm{Fe}, \mathrm{Mn}, \mathrm{Ni}$, and $\mathrm{Zn}$ was observed (Table 4). Several authors have reported a correlation between $\mathrm{Cu}$ and $\mathrm{Zn}$ (Phillips 1976a, b; Riget et al. 1996). Phillips (1976a, b) found that the net uptake of copper by mussel was extremely erratic, and was affected by salinity, temperature changes, and by the presence of other metals and changes in their relative concentrations.

Tissue concentrations of metals observed in mussels in the present study were comparable with earlier studies reported in mussels from the west coast of India (Table 5). Variations in trace metal bioaccumulation being evident within size groups and among exposed and submerged populations, size and depth of sampling ought to be considered in mussel watch 
Table 5. Metal concentrations ( $\mu \mathrm{g} / \mathrm{g}$ tissue weight) reported in green mussel Perna viridis from the west coast of India

\begin{tabular}{|c|c|c|c|c|c|c|c|c|}
\hline Locations & $\mathrm{Cd}$ & $\mathrm{Cu}$ & $\mathrm{Fe}$ & $\mathrm{Mn}$ & $\mathrm{Ni}$ & $\mathrm{Pb}$ & $\mathrm{Zn}$ & Reference \\
\hline Cochin backwaters ${ }^{a}$ & & $22.26 \pm 5.5$ & $374.6 \pm 257.7$ & & & $7.59 \pm 1.27$ & $79.18 \pm 12.14$ & $\begin{array}{l}\text { Lakshmanan and } \\
\text { Nambisan (1983) }\end{array}$ \\
\hline Karwar & $0.31 \pm 0.08$ & $1.50 \pm 0.50$ & & $6.80 \pm 0.76$ & & $0.33 \pm 0.10$ & $14.39 \pm 0.47$ & \\
\hline Majali $^{\text {b }}$ & $0.16 \pm 0.02$ & $1.77 \pm 0.21$ & & $5.24 \pm 0.33$ & & $0.31 \pm 0.03$ & $11.06 \pm 0.23$ & \\
\hline Sungeri Is. ${ }^{\mathrm{b}}$ & $0.15 \pm 0.03$ & $0.86 \pm 0.19$ & & $3.62 \pm 0.69$ & & $0.32 \pm 0.03$ & $11.09 \pm 1.11$ & \\
\hline Devgad Is. & $0.34 \pm 0.08$ & $2.25 \pm 0.32$ & & $6.98 \pm 0.14$ & & $0.50 \pm 0.07$ & $14.54 \pm 0.52$ & $\begin{array}{l}\text { Krishnakumar et al. } \\
\text { (1990) }\end{array}$ \\
\hline $\operatorname{Arga}^{b}$ & $0.22 \pm 0.08$ & $1.57 \pm 0.63$ & $:$ & $8.86 \pm 0.20$ & & $0.80 \pm 0.08$ & $13.97 \pm 2.89$ & \\
\hline Amdalli $^{\mathrm{b}}$ & $0.28 \pm 0.04$ & $2.89 \pm 0.67$ & & $6.18 \pm 0.74$ & & $0.22 \pm 0.06$ & $13.93 \pm 0.25$ & \\
\hline Harwada ${ }^{\mathbf{b}}$ & $0.24 \pm 0.03$ & $2.62 \pm 0.19$ & & $8.10 \pm 0.73$ & & $1.03 \pm 0.42$ & $14.16 \pm 1.10$ & \\
\hline Belekerib & $0.12 \pm 0.06$ & $1.86 \pm 0.21$ & & $6.67 \pm 0.24$ & & $0.26 \pm 0.03$ & $11.62 \pm 0.98$ & \\
\hline Karnataka Majali ${ }^{\text {b }}$ & 0.16 & 1.8 & & & & 0.31 & 11.1 & \\
\hline Karwar $^{\text {b }}$ & 0.31 & 1.5 & & & & 0.33 & 14.4 & \\
\hline $\operatorname{Argae}^{\mathrm{b}}$ & 0.22 & 1.57 & & & & 0.8 & 14 & $\begin{array}{l}\text { Krishnakumar et al. } \\
\text { (1998) }\end{array}$ \\
\hline Kaup $^{\text {b }}$ & 0.54 & 17.1 & & & & 1.48 & 23.3 & \\
\hline Surathkal $^{\text {b }}$ & 0.71 & 23.6 & & & & 1.8 & 49.7 & \\
\hline Thaneerbhavi ${ }^{b}$ & 0.81 & 128 & & & & 2.52 & 70.5 & \\
\hline Gujarat Mocha ${ }^{a}$ & 1.53 & 3.91 & 9.40 & 1.01 & & 20.10 & 37.34 & Tewari et al. (2000) \\
\hline Gujarat Mocha & $4.2-1.08$ & $6.82-21.22$ & $230.6-302.3$ & $5.25-16.28$ & $19.5-53.15$ & $30.56-63.84$ & $40.23-82.8$ & Tewari et al. (2001) \\
\hline Dwaraka $^{a}$ & $2.54-9.48$ & $14.24-40.47$ & $389.4-618.3$ & $12.52-29.54$ & $32.81-65.45$ & $45.28-92.38$ & $52.62-813.28$ & \\
\hline Calicut \& Cochin ${ }^{\mathrm{B}}$ & 2.5 & 7.34 & 16.28 & 0.33 & 2.25 & 6.12 & 344.52 & Radhakrishnan 1993 \\
\hline Karnataka Coast ${ }^{b}$ & $0.03-3.71$ & nd -2.3 & nd-285.4 & $\mathrm{nd}-11.41$ & nd-3.5 & nd -2.00 & nd -34.1 & Present study \\
\hline
\end{tabular}

Dry wt.

bet wt.

programmes. Generally, the levels of toxic trace metals like $\mathrm{Pb}, \mathrm{Cd}, \mathrm{Ni}$, and $\mathrm{Cr}$ in the whole tissue of $P$. viridis were low throughout the coast of Kamataka and within the safe limits. However, relatively high concentrations of $\mathrm{Cd}, \mathrm{Cr}$, and $\mathrm{Pb}$ were observed in the whole tissue of green mussels collected from the coastal waters adjacent to the industrial areas near Mangalore (southern tip of Karnataka), which may be derived from a variety of anthropogenic activities. The trace metal concentrations in the coastal environment of the Karnataka coast need to be monitored on a regular basis due to the rapid increase in industrialization of the area.

Acknowledgments. We are extremely grateful to our Director, Prof. (Dr) Mohan Joseph Modayil, for his encouragement and for facilities provided. We are thankful to Dr. K. K. Appukutan, Head of MF Division; Dr. M. Rajagopalan, Head of FEM Division, Dr. C. Muthiah, Scientist-in-Charge, RC of CMFRI, Mangalore; Dr. Kakati, Scientist-in-Charge, RC of CMFRI, Karwar; and Dr. Prathibha Rohit, Senior Scientist, RC of CMFRI, Mangalore, for their encouragement. We are also thankful to Shri. D. Nagaraja, G. Sampathkumar, Shri. Maruthi Naik, and Smt. Uma S. Bhat for their helpful technical assistance and Dr. Chandra Mohan, Chemical Oceanography Division, School of Marine Sciences, Cochin University of Science and Technology, for AAS facilities.

\section{References}

Appukuttan KK, Kripa V, Velayudhan TS, Mohamed KS, Victor ACC, Kuriakose PS, Laxmilatha P, Muthiah P (2000) Bivalve Mariculture in India: a success story in coastal ecosystem development. In: Pillai VN (ed) Asia Pacific Association of
Agricultural Research Institutions, FAO Regional Office for Asia and the Pacific, Bangkok (APAARI Publication 2000/1), $56 \mathrm{pp}$ Airas S (2003) Trace metal concentration in blue mussels Mytilus edulis (L.) in Byfjorden and the coastal areas of Bergen. Master Thesis, Institute for Fisheries and Marine Biology, University of Bergen, Bergen, Norway, $59 \mathrm{pp}$

Borg H, Jonsson P (1996) Large-scale metal distribution in Baltic Sea sediments. Mar Pollut Bull 32:8-21

Brix H. Lyngby JE (1985) The influence of size upon the concentrations of $\mathrm{Cd}, \mathrm{Cr}, \mathrm{Cu}, \mathrm{Hg}, \mathrm{Pb}$ and $\mathrm{Zn}$ in the common mussel (Mytilus edulis L.). In: Salánki $\mathrm{J}$ (ed) Heavy metals in water organisms. Symposia Biologia Hungarica. Akadémiai Kiadó, Budapest 29:253-271

Central Pollution Control Board (CPCB) (1996) Coastal Pollution. Central Pollution Control Board, Ministry of Environment \& Forests Govt. of India, New Delhi, India, $30 \mathrm{pp}$

Cobelo-Garcia A, Prego R, Labandeira A (2004) Land inputs of trace metals, major elements, particulate organic carbon and suspended solids to an industrial coastal bay of NE Atlantic. Water Res 38:1753-1764

Fowler SW, Oregioni B (1976) Trace metals in mussels from the N.W. Mediterranean. Mar Pollut Bull 7:26-29

Fowler SW (2002) Non-oil industry. The gulf ecosystem: Health and sustainability. In: Khan NY, Munawar M, Price ARG (eds) Ecovision World Monograph Series. Backhuys Publ., Leiden, The Netherlands, pp 157-172

Glynn D, McHugh LTB, Rowe A, Costello J, McGovern E (2003) Trace metal and chlorinated hydrocarbon concentration in shellfish from Irish waters, 2000. Marine Environmental and Health Series, 7. Marine Institute, Marine Environment and Food Safety Services Abbotstown, Dublin, 15 pp

Krishnakumar PK, Pillai VK (1990) Mercury near a caustic soda plant at Karwar, India. Mar Pollut Bull 21:304-307

Krishnakumar PK, Pillai VK, Valsala KK (1990) Bioaccumulation of trace metals by marine flora and fauna near a caustic soda plant (Karwar, India). Ind J Fish 37:129-137 
Krishnakumar PK, Casillas E, Varanasi U (1994) Effects of environmental contaminants on the health of Mytilus edulis from Puget Sound, Washington, USA. I. Cytochemical measures of lysosomal responses in the digestive cells using automatic image analysis. Mar Ecol Prog Ser 106:249-261

Krishnakumar PK, Casillas E, Varanasi U (1995) Effects of environmental contaminants on the health of Mytilus edulis from Puget Sound, Washington, USA. II. Cytochemical detection of subcellular changes in the digestive cells. Mar Biol 124:251-259

Krishnakumar PK, Casillas E, Varanasi U (1997) Cytochemical responses in Mytilus edulis exposed to microencapsulated PAHs and PCBs. Comp Biochem Physiol 118C:11-18

Krishnakumar PK, Bhat GS, Vaidya NG, Pillai VK (1998) Heavy metal distribution in the coastal waters of Karnataka, west coast of India. Ind J Mar Sci 27:201-205

Lakshmanan PT, Nambisan PNK (1983) Seasonal variations in trace metal content in bivalve mollusks, Villorita cyprinoids var. cochinensis (Hanley), Meretrix casta (Chemnitz) \& Perna viridis (Linnaeus). Ind J Mar Sci 12:100-103

Liu JH, Kueh CSW (2005) Biomonitoring of heavy metals and trace organics using the intertidal mussel Perna viridis in Hong Kong coastal waters. Mar Pollut Bull 51:857-875

Mohamed KS, Muthiah C, Nagaraja D, Kumar GS (1998) Initiation of marine mussel culture activities in Dakshina Kannada district, Karnataka. Mar Fish Inform Serv T \& E Ser 155:10-15

Monirith I, Ueno, Takahashi S, Nakata H, Sudaryanto A, Subramanian A, Kauppiah S, Ishmail A, Muchtar M, Zheng J, Richardson BJ, Prudente M, Hue ND, Tana TS, Tkalin AV, Tanabe S (2003) Asia-Pacific mussel watch: monitoring contamination of persistent organochlorine compounds in coastal waters of Asian countries. Mar Pollut Bull 46:281-300

Mohankumar MB, Katti RJ, Moorthy KSV, D'Souza RK (2003) Selected heavy metals in the sediment and macrobenthos of the coastal waters off Mangalore. Indian J Fish 50(2):263-268

Nayar KN, Mahadevan S, Alagaraswami K, Sundaram PTM (eds) (1980) Coastal aquaculture, mussel farming progress and prospects. CMFRI Bull 29:1-56

Nicholson S, Szefer P (2003) Accumulation of metals in the soft tissues, byssus and shell of the mytilid mussel Perna viridis (Bivalvia: Mytilidae) from polluted and uncontaminated locations in Hong Kong coastal waters. Mar Pollut Bull 46:1039-1043

O'Conner T (1992) Recent trends in coastal environmental quality: Results from the first five years of the NOAA Mussel Watch Project. NOAA, Department of Commerce, 1305 East-West Highway, Silver Spring, MD 20910, 46 pp

Otchere FA (2003) Heavy metals concentration and burden in the bivalves (Anadara (Senilia) senilis, Crasostrea ntulipa and Perna perna) from lagoons in Ghana: Model to describe mechanism of accumulation/excretion. Afr J Biotechnol 2(9);280-287

Pempkowiak J, Beldowski J, Pazdro K, Staniszewski A, Zaborska A, Leipe T, Emeis K (2005) Factors influencing fluffy layer suspended matter (FLSM) properties in the Odra River, Pomeranian Bay, Arkona Deep System (Baltic Sea) as derived by principal components analysis (PCA) and cluster analysis (CA). Hydrol Earth Syst Sci 9:67-80

Phillips DJH (1976a) The common mussel Mytilus edulis as an indicator of pollution by zinc, cadmium, lead and copper. 1. Effects of environmental variables on uptake of metals. Mar Biol 38(1):59-69

Phillips DJH (1976b) The common mussel Mytilus edulis as an indicator of pollution by zinc, cadmium, lead and copper. II.
Relationship of metals in the mussel to those discharged by industry. Mar Biol 38:71-80

Radhakrishnan AG (1993) Studies on the trace metal content of fish and shellfish including bivalves. In: Devadasan $\mathrm{K}$ (eds) Nutrients and bioactive substances in aquatic organisms. Society of Fisheries Technologists (India), Cochin, pp 271-275

Rajendran N, Tagore J, Kasinathan R (1988) Heavy metal concentrations in oyster, Crassostrea madrasensis (Preston) of Cuddalore backwaters, southeast coast of India. Ind J Mar Sci 17: 174-175

Ridgwig J, Breward N, Langston WJ, Lister R, Rees JG, Rowlatt SM (2003) Distinguishing between natural and anthropogenic sources of metals entering the Irish Sea. Appl Geochem 18:283-309

Riget F, Johansen P, Asmund G (1996) Influence of length on element concentrations in blue mussels (Mytilus edulis). Mar Pollut Bull 32(10):745-751

Robisch PA, Clark RC (1993) Sample preparation and analyses of trace metals by atomic absorption spectroscopy. In: Lauenstein GG, Cantillo AY (eds) Sampling and analytical methods of the National Status and Trends Program, National Benthic Surveillance Program, and Mussel Watch Project 1984-1992. Vol. III Comprehensive description of elemental analytical methods. NOAA Tech. Memo. NOS ORCA 71, NOAA, Springfield, VA pp $111-150$

Sankaranarayanan VN, Purushan KS, Rao TSS (1978) Concentration of some of the heavy metals in the oyster Crassostrea madrasensis from the Cochin region. Ind J Mar Sci 7:130-131

Schulz-Baldes M (1974) Lead uptake from sea water and food, and lead loss in the common mussel Mytilus edulis. Mar Biol 25:177-193

Sentilnathan S, Balasubrmanian T, Venugopalan VK (1998) Metal concentration in mussel, Perna viridis (Bivalvia/Anisomyaria) and oysters, Crassostrea madrasensis from some parts in southeast coast of India. Ind J Mar Sci 27:206-210

Szefer P, Kim BS, Kim CK, Kin EH, Lee CB (2004) Distribution and coassociations of trace elements in whole tissue and byssus of Mytilus galloprovincialis relative to the surrounding seawater and suspended matter of the southern part of Korean Peninsula. Environ Pollut 129:209-228

Tata Energy Research Institute (TERI) (1999) Measuring, monitoring and managing the sustainability: the coastal dimension. Report No. 1998/WR/41 submitted to European Economic Union. TERI, New Delhi

Tewari A, Joshi HV, Raghunathan C, SravanKumar VG, Kotiwar OS (2000) New record of Mytilus viridis Linn., its density, growth and accumulation of heavy metals on Saurashtra coast, Arabian Sea. Curr Sci 78:97-102

Tewari A, Joshi HV, Raghunathan C, SravanKumar VG, Khambhaty Y (2001) Effect of heavy metal pollution on growth, carotenoid content and bacterial flora in the gut of Perna viridis (L.) in in situ condition. Curr Sci 81:819-828

WHO (World Health Organisation) (1972) Evaluation of certain food additives and the contaminants mercury, lead, cadmium. 16th Report of the Joint FAO/WHO Expert Committee on Food Additives. Technical Report Series 505, Geneva

WHO (World Health Organisation) (1987) Evaluation of certain food additives and contaminants. 33rd Report of the joint FAO/WHO Expert Committee on Food Additives. WHO Technical Report Series 776 , Geneva, 80 pp

Zingde MD, Singbal SYS, Moraes CF, Reddy CVG (1976) Arsenic, copper, zinc and manganese in the marine flora and fauna of coastal estuarine waters around Goa. Indian J Mar Sci 5:212-217 